\title{
Homocysteine Levels and Osteoporotic Fracture in a Population Aged 55 Years Over in Medan District Indonesia
}

\author{
Sry Suryani Widjaja ${ }^{1 *} \mathbb{D}$, Rusdiana Rusdiana ${ }^{1} \mathbb{D}$, Vito Filbert Jayalie ${ }^{2}$ \\ ${ }^{1}$ Department of Biochemistry, Universitas Sumatera Utara, Medan, Indonesia; ${ }^{2}$ Department of Radiation Oncology, Universitas \\ Indonesia, Jakarta, Indonesia
}

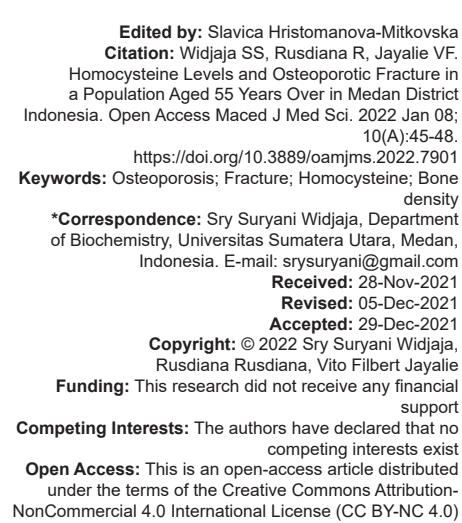

\section{Introduction}

Osteoporosis is a chronic, progressive, systemic, skeletal, multifactorial disorder characterized by low bone mass, microarchitectural deterioration of bone tissues [1], [2], [3] that increased the risk of fragility fracture [1], is a leading cause of fracture in old age, causing pain, hospitalization, poor quality of life and financial burden [4]. It is estimated that 1 in 3 women and 1 in 5 men above the age of 50 will get osteoporotic fractures [5], with the most common sites are the spine, hip, and wrist [1]. This will increased the morbidity and mortality rate also the socio-economic burden [3].

Homocysteine is an amino acid that contains sulfur which formed through the process of changing methionine to cystathionine during the metabolism of methionine [6], [7], is identified as a new risk factor of osteoporosis [8]. The elevated level of homocysteine in the blood will result as homocystinuria which is an autosomal recessive disorder that believed to cause eye disorders, blood vessels, central nervous system damaged, and early osteoporosis [2], [9]. The increased levels of homocysteine will increase the risk of fracture especially in post-menopausal female, by causing oxidative damage to the bones, increased bone resorption, and reducing bone quality [10], [11], also interfere with the normal calcification process [12].

The increased prevalence of earlyosteoporosis in homocystinuria illustrates that homocysteine metabolism is involved in the process of osteoporosis [2], [13]. This process was first suggested by Mc Kussick stating that homocysteine is likely to interfere with collagen crosslinking in the bone [2], [13], this effect may be due to the inhibition of enzyme lysyl oxidase which forms collagen cross-links and stabile the bone matrix [11], and increased osteoclast activity in response to elevated homocysteine level [14]. Homocysteine could be used to predict susceptibility to osteoporotic fractures independent of bone mineral density [2], [15] though the relationship between homocysteine and bone mineral density still controversial [16], [17], [18].

In the elderly, rate of bone loss increased dramatically especially in women after menopause [19], and homocysteine is identified as a new risk factor that leads to osteoporosis [8]. 


\section{Objectives}

This study was aimed to look for the relationship between homocysteine levels in the blood and the occurrence of osteoporotic fractures in the population above 55 years old in an Elderly Nursing Home Community and population from healthy gymnastics in Medan Town Indonesia.

\section{Methods}

This is a descriptive study with cross-sectional approach. The research was done after the approval of ethical clearance, and the subjects signed the informed consent. The subjects of the study were the population aged 55 years or older, who had an osteoporosis fracture and as a control population aged 55 years or more without osteoporotic fracture. Samples were collected with a simple random sampling method from an Elderly Nursing Home Community and healthy gymnastics in Medan Town Indonesia. Total sixtyfive patients aged 55 years or older who fulfilled the inclusion and exclusion criteria were recruited. Data were analyzed using Statistical Package for the Social Sciences 23 version.

The inclusion criteria were populations aged 55 years or older, do not suffer from diabetes, malignancy and are not currently taking steroid drugs, supplements of Vitamin B12, B6 folic acid, and hormone replacement therapy. The exclusion criteria were pregnancy, breastfeeding, vegetarian, malignancy. Every responder will be asked to fill the questionnaires that include the biodata, history of the diseases, family history diseases, history of taking vitamin B6, B12, folic acid, and hormones. Blood pressure, heart rate, and body weight were recorded, bone density was measured using central dual-energy x-ray absorptiometry (DXA) machine/DXA, and homocysteine plasma levels were measured using the enzyme-linked immunoassay method.

\section{Homocysteine measurement}

Patients need to be fasted for at least $8 \mathrm{~h}$. 3 cc EDTA blood samples were collected and plasma was separated immediately within $1 \mathrm{~h}$ with centrifuge at speed 1000 RPM for 10 min. After separation. Assay for homocysteine will be done immediately or will be store in $-80^{\circ} \mathrm{C}$ until assay done.

\section{Bone density measurement}

Osteoporosis was diagnosed by measure the bone density of the hip and spine using the central DXA machine. Using the reference databases $T$ scores were computed by DXA machine software. According to the World Health Organization: T score of -1.0 or above is considered normal bone density, $\mathrm{T}$ score between -1.0 and -2.5 is considered low bone density or osteopenia and T score of -2.5 or below is a diagnosis of osteoporosis.

\section{Results}

A descriptive-analytic study with a crosssectional approach has been carried out on populations aged 55 years or older in the number of nursing homes in Karya Kasih Mongonsidi and healthy gymnastics groups in the Medan Plaza Medan parking lot. Obtained a sample of 65 people who met the inclusion criteria.

The number of samples who had osteoporosis fractures were 15 people and those without fractures were 50 people. The age range of the samples obtained is between 55 and 88 years. Kolmogorov-Smirnov Test was used to determine the normality of the variables and Spearman's rho correlation was used to determine the correlation between variables measured.

From the Table 1 we got a group where the homocysteine levels were far above the average levels, and in fact, this is a group with comorbid such as hypertension and diabetes. (data got from the questionnaires).

Table 1: Baseline characteristic of the samples

\begin{tabular}{lcccc}
\hline Data & Age & Homocysteine level & T-SCORE & BMI \\
\hline $\mathrm{n}$ (total samples) & 65 & 65 & 65 & 65 \\
Mean \pm SD & $68.8 \pm 8.6$ & $12.4 \pm 4.2$ & $-2.6 \pm 1.7$ & $24.7 \pm 4.9$ \\
Range & $55-88$ & $4.43-25.11$ & $-6.9-0.9$ & $18-41$ \\
\hline BMI: Body mass index. & & & &
\end{tabular}

From the Tables 2 and 3, they were 38 peoples with osteoporosis, which 12 got the osteoporotic fracture. Among the 16 people in the osteopenia group, two got the fracture, among 11 peoples with normal bone density, one got the osteoporotic fracture. Pearson correlation was used to analyzed the data, there was significant result between fracture and bone mineral density $(p=0.00)$ and no statistical significant between bone density and gender $(p=0.08)$, bone density, and body mass index (BMI) $(p=0.11)$.

Table 2: Distribution of bone mineral density

\begin{tabular}{lll}
\hline Bone mineral density & Frequency & Percentage \\
\hline 1 (Osteoporosis) & 38 & 58.46 \\
2 (Osteopenia) & 16 & 24.62 \\
3 (Normal) & 11 & 16.92 \\
Total & 65 & 100.00 \\
\hline
\end{tabular}

There was statistical significant correlation between homocysteine and age $(p=0.02)$, age and bone density ( $p=0.002$ ), homocysteine and bone density ( $p$ $=0.0$ ), but no statistical significant correlation between homocysteine and BMI ( $p=0.07)$, homocysteine and osteoporotic fracture $(p=0.87)$. 
Table 3: Distribution incidence of fracture according to bone mineral density

\begin{tabular}{lllll}
\hline Bone condition & Osteoporosis & Osteopenia & Normal & Total \\
\hline Fracture & 12 & 2 & 1 & 15 \\
No fracture & 26 & 13 & 10 & 50 \\
Total & 38 & 16 & 11 & 65 \\
\hline
\end{tabular}

\section{Discussion}

In this study, we got a statistical significant correlation between homocysteine and bone mineral density, this is contrary to the results of the study of Van Meurs et al. in New England Journal of Medicine (NEJM) 2004, where they stated no significant relationship between homocysteine and bone density [2]. This may be due to the differences of the population of samples. But the significant correlation between bone density and fractures supports the study of Van Meurs et al. [2]. It was found that bone density did not have a significant relationship with gender and BMI, whereas according to Kanis et al. in the Osteoporosis training course in Singapore, bone density was affected by BMI, samples with low BMI were more likely to have low density. We do not found correlation between homocysteine and incidence of osteoporotic fracture, this was contrary with the results reported by Van Meurs et al. in NEJM 2004. Between age and homocysteine, there was a weak relationship, this is different from what is stated in the Text Book of Biochemistry with Clinical Correlations by Thomas, where it stated that homocysteine levels are affected by age, and increase throughout live in both women and men (according to Welch and Loscalzo in NEJM article 1998). In this study, we also found that there is a correlation between age and bone density, as stated in the Textbook of Clinical Medicine by Kumar chapter Osteoporosis. Homocysteine remains an important issue to be explored though there were many controversial studies whether it plays an important part in some degenerative diseases or not.

\section{Conclusions}

The elevated homocysteine level did not increased the incidence of osteoporotic fracture, however, homocysteine increased with aging and correlated with bone mineral density.

\section{References}

1. World Health Organization. Assessment of Fracture Risk and its Application to Screening for Postmenopausal Osteoporosis.
Report of a WHO Study Group. Geneva: World Health Organization; 1994.

2. Van Meurs JB, Dhonukshe-Rutten RA, Pluijm SM, van der Klift M, de Jonge R, Lindemans $\mathrm{J}$, et al. Homocysteine levels and the risk of osteoporotic fracture. N Eng J Med. 2004;350(20):203341. https://doi.org/10.1056/NEJMoa032546

PMid: 15141041

3. Van Wijngaarden JP, Doets EL, Szczecińska A, Souverein OW, Duffy ME, Dullemeijer C, et al. Vitamin B12, folate, homocysteine, and bone health in adults and elderly people: A systematic review with meta-analyses. Nutr Metable. 2013;2013:486186. https://doi.org/10.1155/2013/486186

PMid:23509616

4. Górski R, Chmielewski D, Zgoda M. The evaluation of social awareness of osteoporosis: Based on the aimed questionnaire. Ortop Traumatol Rehabil. 2006;8(6):627-32.

PMid: 17581512

5. Kanis JA, Johnell O, Oden A, Sembo I, Redlund-Johnell I, Dawson $A$, et al. Long-term risk of osteoporotic fracture in Malmö. Osteoporos Int. 2000;11(8):669-74. https://doi. org/10.1007/s001980070064

\section{PMid:11095169}

6. Devlin M. Thomas,editor. Text book of biochemistry with clinical correlations.5 ed. Wiley-Liss Publication;2002.803-6.

7. Mudd SH, Skooby F, Levy H, Pettigrew KD, Wilcken B, Pyeritz RE, et al. The natural history of homocysteinedue to cystathionine beta-synthase deficiency. Am J Hum Genet. 1985;37(1):1-31.

PMid:3872065

8. Herrmann M, Schmidt JP, Umanskaya N, Wagner A, TabanShomal O, Widmann T, et al. The role of hyperhomocysteinemia as well as folate, Vitamin B6 and B12 deficiencies in osteoporosis: A systematic review. Choose Destination Clin Chem Lab Med. 2007;45(12):1621-32. https://doi.org/10.1515/CCLM.2007.362 PMid: 18067447

9. Welch GN, Loscalzo J. Homocysteine and atherothrombosis. New Eng J Med. 1998;338(15):1042-50. https://doi.org/10.1056/ NEJM199804093381507

PMid:9535670

10. Koh JM, Lee YS, Kim YS, Kim DJ, Kim HH, Park JY, et al. Homocysteine enhances bone resorption by stimulation of osteoclast formation and activity through increased intracellular ROS generation. J Bone Miner Res. 2006;21(7):1003-11. https://doi.org/10.1359/jbmr.060406

PMid:16813521

11. Thaler R, Agsten M, Spitzer S, Paschalis EP, Karlic $H$, Klaushofer $\mathrm{K}$, et al. Homocysteine suppresses the expression of the collagen cross-linker lysyl oxidase involving IL-6, Fli1, and epigenetic DNA methylation. J Biol Chem. 2011;286(7):557888. https://doi.org/10.1074/jbc.M110.166181

PMid:21148317

12. Lubec $B$, Fang $K S$, Lubec $T$, Blom HJ, Boers $G H$ Evidence for McKusick's hypothesis of deficient collagen cross-linking in patients with homocysteinuria. Biochem Biophys Acta. 1996;1315(3):159-62. https://doi. org/10.1016/0925-4439(95)00119-0 PMid:8611653

13. Mc Lean RR, Jacques PF. Homocysteine as a predictive factor for hip fracture in older persons. N Eng J Med. 2004;350(20):20429. https://doi.org/10.1056/NEJMoa032739 PMid:15141042

14. Herrmann M, Umanskaya N, Wildemann B, Colaianni G Widmann T, Zallone A, et al. Stimulation of osteoblast activity by homocysteine. J Cell Mol Med. 2008;12(4):1205-10. https://doi. org/10.1111/j.1582-4934.2008.00104.x 


\section{PMid:18782184}

15. Shiraki M, Kuroda T, Shiraki Y, Tanaka S, Higuchi T, Saito M Urinary pentosidine and plasma homocysteine levels at baseline predict future fractures in osteoporosis patients under bisphosphonate treatment. J Bone Miner Metab. 2011;29(1):6270. https://doi.org/10.1007/s00774-010-0191-2 PMid:20458602

16. Bahtiri E, Islami I, Rexhepi S, Qorraj-Bytyqi H, Thaçi K, Thaçi S, et al. Relationship of homocysteine levels with lumbar spine and femur neck BMD in postmenopausal women. Acta Rheumatol Port. 2015;40(4):355-62.

PMid:26922199

17. Kim JI, Moon JH, Chung HW, Kong MH, Kim HJ. Association between homocysteine and bone mineral density according to age and sex in healthy adults. J Bone Metab. 2016;2(3):129-34. https://doi.org/10.11005/jbm.2016.23.3.129

PMid:27622176

18. Tariq S, Lone KP, Tariq S. Comparison of parameters of bone profile and homocysteine in physically active and non-active postmenopausal females. Pak J Med Sci. 2016;32(5):1263-7. https://doi.org/10.12669/pjms.325.10655

PMid:27882033

19. Heaney RP. Dairy and bone health. J Am Coll Nutr. 2009;28(Suppl 1):82-90. https://doi.org/10.1080/07315724.200 9.10719808

PMid:19571166 